\title{
PENINGKATAN AKTIVITAS DAN KEMAMPUAN MENULIS KARANGAN DESKRIPSI MELALUI PENGGUNAAN PETA KONSEP PADA SISWA KELAS IV SD 09 V KOTO KAMPUNG DALAM KABUPATEN PADANG PARIAMAN
}

\section{KASMABOTI}

\section{Abstrak}

Penelitian ini dilatarbelakangi oleh kurangnya kemampuan siswa dalam menulis karangan karena masih ditemukan kesalahan dalam karangan siswa, seperti kalimat yang digunakan kurang runtut atau bolak-balik dan ide yang digunakan masih kaku/sempit. Kerancuan karangan juga terlihat dari segi kelengkapan paragraf yang dibuat. Paragraf-paragraf yang dibuat siswa kurang padu atau kurang terlihat adanya hubungan antar paragraf sehingga nilai siswa dalam menulis rendah. Tujuan penelitian ini adalah agar siswa dapat meningkatkan aktivitas dan kemampuan menulis karangan deskripsi dengan menggunakan peta konsep.

Teori yang digunakan dalam penelitian ini adalah teori pembelajaran aktivitas menurut Dierich, kemampuan menulis karangan deskripsi menurut Muchlisoh dengan peta konsep menurut Nur Afrita.

Metode penelitian yang diterapkan adalah metode penelitian tindakan kelas. Penelitian ini dilaksanakan dua siklus, masing-masing siklus terdiri atas dua kali pertemuan. Subjek penelitian ini adalah siswa kelas IV SD 09 V Koto Kampung Dalam yang berjumlah 36 orang. Instrumen penelitian yang digunakan dalam penelitian adalah lembar observasi aktivitas siswa, lembar observasi aktivitas guru dan tes hasil belajar.

Berdasarkan hasil penelitian yang dilaksanakan di kelas IV SD 09 V Koto Kampung Dalam, penggunaan peta konsep terbukti dapat meningkatkan kemampuan menulis karangan deskripsi siswa. Ini dapat dilihat pada siklus I tahap prapenulisan, penulisan, dan pascapenulisan dengan rata-rata nilai 75,77 . Sedangkan pada siklus II tahap prapenulisan, penulisan, dan pascapenulisan dengan rata-rata nilai 78,53 dengan peningkatan sebesar 2,76.

Berdasarkan hal tersebut di atas dapat dikatakan bahwa peta konsep dapat meningkatkan aktivitas dan kemampuan menulis karangan deskripsi siswa, untuk itu disarankan kepada guru untuk dapat menggunakan peta konsep dalam melaksanakan pembelajaran menulis.

Keyword: Aktivitas, Peta Konsep, Menulis Karangan Deskripsi.

Copyright (C) 2016 IICET (Padang - Indonesia) - All Rights Reserved Indonesian Institute for Counseling, Education and Theraphy (IICET)

\section{PENDAHULUAN}

Menulis merupakan suatu kegiatan yang tidak dapat dipisahkan dari aktivitas kehidupan manusia. Menurut Depdikbud (dalam Resmini dan Juanda, 2007:115), "Menulis ialah membuat huruf atau langkah, dan sebagainya dengan pena, melahirkan pikiran dan perasaan seperti mengarang, membuat surat dengan tulisan, mengarang di majalah, mengarang roman atau cerita, membuat surat."Berdasarkan pendapat mengenai pengertian menulis yang diuraikan, dapat disimpulkan bahwa menulis merupakan suatu keterampilan berbahasa yang digunakan sebagai alat komunikasi secara tidak langsung antara penulis dan pembaca dalam ragam bahasa tulisan.

Menulis karangan adalah salah satu bentuk kemampuan berbahasa yang dituntut dalam Kurikulum Tingkat Satuan Pendidikan (KTSP) 2006. Hal itu yang terdapat pada kompetensi dasar 8.1 pada kelas IV semester II, yaitu menyusun karangan tentang berbagai topik sederhana dengan memperhatikan penggunaan ejaan (huruf besar, tanda titik, tanda koma dan lain-lain). Dalam pembelajaran menulis deskripsi di kelas IV Sekolah Dasar, siswa dituntut untuk dapat membuat karangan yang melukiskan suatu keadaan, objek, tempat maupun manusia secara detail dengan menggunakan ejaan yang disempurnakan (EYD) secara tepat serta ditunjang oleh ide-ide, imajinasi dan gaya berbahasa yang dimiliki siswa. 
Berdasarkan observasi dan wawancara yang peneliti lakukan dengan ibu Eli Erlina guru kelas IV SD 09 V Koto Kampung Dalam pada tanggal 24 September 2012, disimpulkan bahwa masih ditemukan kesalahan dalam karangan siswa, seperti kalimat yang digunakan kurang runtut atau bolak-balik dan ide yang digunakan masih kaku/sempit. Kerancuan karangan juga terlihat dari segi kelengkapan paragraf yang dibuat. Paragraf-paragraf yang dibuat siswa kurang padu atau kurang terlihat adanya hubungan antar paragraf sehingga nilai siswa dalam menulis rendah.

Secara singkat dapat dikatakan bahwa kemampuan menulis karangan siswa kelas IV SD 09 V Koto Kampung Dalam masih rendah. Adapun penyebab dari masalah ini adalah guru kurang menerapkan langkahlangkah dalam mengarang. Guru hanya memberikan tema karangan kemudian siswa ditugaskan membuat karangan dengan tema yang telah ditentukan. Setelah siswa menulis karangan, siswa tidak menempatkan tahapan-tahapan pasca penulisan seperti merevisi, mengedit dan publikasi. Selain itu, berdasarkan dari hasil ulangan harian pertama diperoleh hasil yang masih belum mencapai KKM (Kriteria Ketuntasan Minimum) yang ditetapkan sebenarnya yaitu 75 . Dari 36 orang siswa masih ada 15 orang siswa yang nilainya di bawah 75 .

Fakta yang ada membutuhkan penelitian tindakan kelas untuk meningkatkan aktivitas belajar dan kemampuan menulis karangan deskrispsi bagi siswa di kelas IV SD 09 V Koto Kampung Dalam. Dalam hal ini, peneliti akan mengajak siswa menggunakan peta konsep dalam mengumpulkan ciri-ciri dan keterangan dari objek yang akan dideskripsikan. Selanjutnya, keterangan dari objek yang telah terkumpul ini dikembangkan menjadi kerangka karangan. Kemudian, kerangka karangan ini dikembangkan menjadi karangan utuh. Seperti yang telah dipaparkan di atas, peneliti menggunakan peta konsep dalam mengumpulkan keterangan dari suatu objek yang diamati karena sebagian besar siswa SD kurang bisa mengorganisasikan apa-apa yang dilihat, dirasakan, dan yang dialaminya dalam kalimat bahasa yang baik. Dengan menggunakan peta konsep, siswa diharapkan dapat mengumpulkan informasi/keterangan dari objek yang akan dideskripsikan secara lebih terperinci serta mencegah terjadinya pengulangan kalimat yang sama yang menggambarkan perincian dari objek. Dengan demikian, karangan yang dihasilkan siswa lebih terstruktur, berkesinambungan dan terperinci. Berdasarkan permasalahan yang telah ditemukan, peneliti tertarik untuk melakukan penelitian dengan judul "Peningkatan Aktivitas dan Kemampuan Menulis Karangan Deskripsi Melalui Penggunaan Peta Konsep pada siswa kelas IV SD 09 V Koto Kampung Dalam’.

\section{METODELOGI PENELITIAN}

Jenis penelitian yang digunakan adalah tindakan kelas. Menurut Wardani (2003:1.4), "Penelitian tindakan kelas adalah penelitian yang dilakukan oleh guru di dalam kelasnya sendiri melalui refleksi diri, dengan tujuan untuk memperbaiki kinerjanya sebagai seorang guru sehingga hasil belajar siswa meningkat". Penelitian ini dilaksanakan di kelas IV SD 09 V Koto Kampung Dalam,. Subjek penelitian berjumlah 37 orang yang terdiri dari laki-laki sebanyak 18 orang serta perempuan 19 orang. Penelitian tindakan kelas ini direncanakan akan dilakukan dalam beberapa siklus, dengan masing-masing satu siklusnya terdiri dari 3 kali pertemuan.

Indikator keberhasilan pada penelitian ini adalah apabila persentase aktivitas belajar siswa dalam pembelajaran sudah masuk dalam kategori baik dan sangat baik $(>60 \%)$ untuk indikator positif dan kategori kurang dan sangat kurang $(\leq 40 \%)$ untuk indikator negatif. Siswa dikatakan tuntas belajar apabila telah mencapai acuan standar Kriteria Ketuntasan Minimal (KKM) yang ditetapkan oleh sekolah tempat penelitian yaitu 75. Ketuntasan belajar secara klasikal apabila sudah mencapai $\geq 80 \%$ dan rata-rata hasil belajar $>75$.

Data yang sudah diolah ke dalam bentuk persentase tersebut dapat dikategorikan menjadi 5 kriteria, sebagaimana yang dikemukakan oleh Suharsimi dalam Erlynda (2007:31) sebagai berikut:

\section{Kriteria Penilaian Aktivitas Belajar Siswa}

\begin{tabular}{|c|c|c|}
\hline $\begin{array}{c}\text { Persentase Aktivitas Belajar } \\
\text { (Kuantitatif) }\end{array}$ & \multicolumn{2}{|c|}{$\begin{array}{c}\text { Aktivitas Belajar } \\
\text { (Kualitatif) }\end{array}$} \\
\cline { 2 - 3 } & Indikator Positif & Indikator Negatif \\
\hline $0 \% \leq \mathrm{AB} \leq 20 \%$ & Kurang Sekali(BS) & Baik Sekali (BS) \\
\hline
\end{tabular}




\begin{tabular}{|c|c|c|}
\hline $21 \% \leq \mathrm{AB} \leq 40 \%$ & $\operatorname{Kurang}(\mathrm{K})$ & Baik(B) \\
\hline $41 \% \leq \mathrm{AB} \leq 60 \%$ & Cukup(C) & Cukup (C) \\
\hline $61 \% \leq \mathrm{AB} \leq 80 \%$ & Baik(B) & Buruk (K) \\
\hline $81 \% \leq \mathrm{AB} \leq 100 \%$ & Baik Sekali (BS) & Buruk Sekali (BS) \\
\hline
\end{tabular}

Keterangan: $\mathbf{A B}=$ Aktivitas Belajar

\section{HASIL DAN PEMBAHASAN PENELITIAN \\ HASIL PENELITIAN \\ Siklus I \\ Perencanaan}

Peningkatan kemampuan menulis karangan deskripsi dengan menggunakan peta konsep disusun dalam bentuk rencana pembelajaran yang dikenal dengan sebutan RPP disusun berdasarkan program semester II yang terdiri dari satuan pendidikan, mata pelajaran, tema, alokasi waktu, standar kompetensi, kompetensi dasar, indikator pembelajaran, materi, proses pelaksanaan pembelajaran, media dan metode yang digunakan, sumber, dan evaluasi.

Pada siklus I ini temanya adalah diri sendiri dan alokasi waktunya 4 X 35 menit yang dilaksanakan dalam dua kali pertemuan. Standar kompetensi dari pembelajaran menulis karangan deskripsi yaitu "Mengungkapkan pikiran, perasaan, dan informasi dalam bentuk karangan, pengumuman, dan pantun anak". Sedangkan kompetensi dasarnya (KD) adalah: "Menyusun karangan tentang berbagai topik sederhana dengan memperhatikan penggunaan ejaan (huruf besar, tanda titik, tanda koma, dll). Dari KD yang telah diambil, kemudian peneliti merumuskan indikator pembelajaran sebagai berikut:

(1) Membuat peta konsep dari objek yang akan dideskripsikan.

(2) Mengumpulkan ciri-ciri dari objek dengan menggunakan peta konsep

(3) Menyusun kerangka karangan berdasarkan peta konsep yang dibuat.

(4) Mengembangkan kerangka karangan menjadi karangan utuh.

Untuk mencapai indikator di atas, kegiatan pembelajaran dibagi menjadi 3 tahap yaitu tahap prapenulisan, tahap penulisan, dan tahap pascapenulisan. Kegiatan pembelajaran terbagi menjadi kegiatan guru dan kegiatan siswa supaya jelas terlihat apa-apa yang harus dilakukan guru dan apa yang harus dilakukan oleh siswa. Hal ini juga dilakukan untuk mempermudah observer dalam mengisi lembaran pencatatan lapangan.

Adapun yang peneliti lakukan pada tahap prapenulisan ini adalah (1) mengkondisikan kelas, (2) meminta siswa berdoa, (3) mengambil absensi siswa, (4) menghangatkan suasana kelas sekaligus membua skemata siswa dengan menyanyikan lagu lihat kebunku, (5) melakukan tanya jawab tentang gambaran tentang bunga kemudian mengatakan kepada siswa bahwa yang telah dilakukan siswa adalah mendeskripsikan bunga, (6) mengarahkan siswa dalam menarik pengertian karangan deskripsi, (7) menjelaskan kepada siswa bahwa salah satu cara untuk menulis karangan deskripsi dengan mudah adalah dengan menggunakan peta konsep, (8) menetapkan teman di sebelah bangku masing-masing siswa sebagai objek yang akan dideskripsikan, (9) membagikan kertas HVS berbingkai sebagai wadah membuat peta konsep, (10) membimbing siswa dalam membuat peta konsep dengan mencontohkan langkah membuat peta konsep tahap demi tahap, (11) mengarahkan siswa dalam mengumpulkan ciri-ciri teman sebelah bangkunya dengan menggunakan peta konsep yang sudah dibuat, dan (12) mengarahkan siswa dalam membuat kerangka karangan berdasarkan ciriciri dari temannya yang telah terkumpul dalam peta konsep.

Pada tahap penulisan peneliti mengarahkan siswa dalam mengembangkan kerangka karangan menjadi karangan deskripsi dengan jalan membahasakan kembali kalimat-kalimat sederhana yang terdapat dalam kerangka karangan menjadi kalimat bahasa yang menarik. Di samping itu, peneliti juga mengingatkan siswa tentang ketentuan pemakaian huruf kapital, tanda baca, kata sambung, serta pemenggalan kata. Pada tahap pascapenulisan peneliti mengarahkan siswa merevisi karangan, melakukan pengeditan, dan menyalin kembali karangan yang sudah dibuat. Kemudian karangan yang sudah disalin dikumpulkan.

Pelaksanaan Siklus I

Sesuai dengan perencanaan, pelaksanaan pembelajaran menulis karangan deskripsi dengan menggunakan peta konsep terbagi menjadi tiga tahap. Tahap pertama yaitu tahap prapenulisan, tahap kedua penulisan, dan tahap ketiga pascapenulisan. Pelaksanaan siklus I dibagi menjadi dua kali pertemuan. Pertemuan pertama dilakukan pada hari Selasa, tanggal 14 Mei 2013 dari pukul 10.00 sampai 11.30 
kemudian pertemuan kedua dilakukan pada hari Kamis, tanggal 16 Mei 2013 setelah jam istirahat yaitu dari pukul 10.00 sampai pukul 11.30.

Pada tahap prapenulisan dimulai dengan mengatur posisi tempat duduk siswa, kemudian melakukan doa secara bersama. Sebelum dan sesudah berdoa peneliti menyelipkan beberapa pesan moral dan pesan agama Islam kepada siswa (mengingat seluruh siswanya beragama Islam). Pesan yang peneliti sampaikan diantaranya adalah pesan hukum mengerjakan suatu pekerjaan jika tanpa menyebut nama Allah maka pekerjaan yang dilakukan sama artinya dengan pekerjaan syaitan.

Setelah siswa berdoa, dilakukan pengambilan absensi siswa. Kemudian peneliti menghangatkan suasana dan merilekskan tubuh dan pemikiran siswa dengan melakukan permainan, menyanyikan lagu yang menggambarkan tentang suatu benda/objek. Adapun lagu yang dinyanyikan adalah nada lihat kebunku. Setelah menyanyikan syair lagu di atas, peneliti melakukan tanya jawab tentang bentuk bunga. Kemudian dilakukan tanyajwab tentang karangan deskripsi.

Siswa dapat menyebutkan pengertian karangan deskripsi, kemudian peneliti menjelaskan tujuan dan langkah-langkah menulis karangan deskripsi. Salah satu langkah-langkah menulis karangan deskripsi adalah mengamati objek/benda yang akan dideskripsikan, kemudian mengumpulkan keterangan/ciri-ciri dari objek/benda yang diamati. Selanjutnya, peneliti menjelaskan kepada siswa bahwa untuk memudahkan pengumpulan keterangan/ciri-ciri dari objek yang diamati dapat digunakan peta konsep. Kemudian peneliti dan siswa menyepakati untuk menjadikan teman sebangku sebagai objek yang akan dideskripsikan.

Setelah keterangan dari objek yang diamati terkumpul dalam bentuk peta konsep, peneliti membagikan kertas HVS kepada siswa. Setelah siswa membuat tanggal, nama dan kelasnya, peneliti pun mencontohkan cara memasukkan keterangan dari objek yang diamati menjadi kerangka karangan. Peneliti hanya mencontohkan sebuah kerangka paragraf, karena kerangka karangan terdiri dari beberapa kerangka paragraf. Kemudian, peneliti meminta siswa membuat kerangka paragraf untuk ide penunjang lainnya sehingga menjadi kerangka karangan. Setelah kerangka karangan selesai, peneliti memeriksa kerangka karangan yang sudah dibuat siswa untuk memastikan apakah keterangan dari objek yang diamati siswa sudah dituangkan seluruhnya menjadi kerangka karangan atau tidak.

Pada tahap penulisan ini siswa mengembangkan kerangka karangan yang telah dibuatnya menjadi karangan deskripsi utuh. Pada saat ini peneliti juga mencontohkan cara mengembangkan kerangka paragraf sehingga menjadi paragraf utuh. Kemudian, untuk megembangkan kerangka karangan seterusnya diserahkan kepada siswa. Peneliti terus mengawasi dan membimbing siswa dalam menuangkan idenya menjadi karangan utuh.

Setelah perevisian dan pengeditan dilakukan, siswa mengembalikan karangan yang telah direvisi dan diedit kepada teman yang bersangkutan. Langkah selanjutnya siswa menyalin kembali karangan yang sudah direvisi dan diedit. Kemudian peneliti menyeleksi karangan siswa. Karangan terbaik akan diberi kesempatan untuk dibacakan. Setelah pelaksanaan pembelajaran berakhir, semua lembaran kertas dikumpulkan (peta konsep, kerangka karangan, karangan sebelum direvisi dan diedit, serta karangan setelah direvisi dan diedit). Peneliti melakukan penilaian terhadap karangan yang sudah dibuat siswa. Penilaian peta konsep dilihat dari segi perincian keterangan, kebersihan, dan pilihan kata kunci yang digunakan. Penilaian kerangka karangan dilihat dari segi cocok atau tidaknya perincian dari peta konsep dengan kerangka karangan yang dibuat. Selain itu juga dilihat pembahasaan kata kunci hingga menjadi kalimat sederhana dalam kerangka karangan.

Penilaian karangan sebelum diperbaiki dan setelah diperbaiki dilihat dari segi penyampaian ide/gagasan, pengorganisasian karangan, gaya bahasa, dan mekanisme tulisan. Penilaian terhadap ide/gagasan dilihat dari segi kreatifitas, kelayakan dan kelogisan penyajiannya. Penilaian terhadap pengorganisasian karangan dilihat dari segi kalimat utama, pola kalimat dan pilihan kata penyusun kalimat. Gaya bahasa dilihat dari segi deskripstif atau tidaknya bahasa yang digunakan, bervariasi atau tidaknya kalimat yang digunakan, serta mudah atau tidak dipahami bahasa yang digunakan. Sedangkan mekanisme penulisan karangan dilihat dari segi penggunaan tanda baca dan penggunaan huruf kapital yang sesuai dengan EYD, serta ketelitian dalam menulis (tinggal/tidaknya huruf-huruf dalam menuliskan kalimat).

\section{Pengamatan}

Hasil pengamatan terhadap hasil pembelajaran Menulis Karangan Deskripsi Dengan Menggunakan Peta Konsep sebagai berikut: 
Tabel 1.

Rekapitulasi Nilai Siswa Menulis Karangan Deskripsi Menggunakan Peta Konsep pada Siklus I

\begin{tabular}{|c|c|c|c|c|c|c|c|}
\hline \multirow[b]{2}{*}{ No } & \multirow[b]{2}{*}{ Nama Siswa } & \multicolumn{3}{|c|}{ POIN PENILAIAN (\%) } & \multirow[b]{2}{*}{ Jumlah } & \multirow[b]{2}{*}{$\begin{array}{l}\text { Nilai } \\
\text { Akhir } \\
(\%)\end{array}$} & \multirow[b]{2}{*}{ 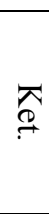 } \\
\hline & & $\begin{array}{c}\text { Peta } \\
\text { Konsep }\end{array}$ & $\begin{array}{c}\text { Kerang } \\
\text { ka } \\
\text { Karanga } \\
\text { n }\end{array}$ & $\begin{array}{c}\text { Hasil } \\
\text { Karanga } \\
\text { n }\end{array}$ & & & \\
\hline 1 & WA & 66,67 & 66,67 & 62,5 & 195,84 & 65,28 & $X$ \\
\hline 2 & $\mathrm{RD}$ & 75 & 75 & 75 & 225,00 & 75,00 & $\sqrt{ }$ \\
\hline 3 & MR & 75 & 75 & 81,25 & 231,25 & 77,08 & $\sqrt{ }$ \\
\hline 4 & $\mathrm{HR}$ & 75 & 66,67 & 81,25 & 222,92 & 74,31 & $\mathrm{X}$ \\
\hline 5 & AJ & 83,33 & 75 & 81,25 & 239,58 & 79,86 & $\sqrt{ }$ \\
\hline 6 & IY & 83,33 & 83,33 & 81,25 & 247,91 & 82,64 & $\sqrt{ }$ \\
\hline 7 & LS & 75 & 66,67 & 68,75 & 210,42 & 70,14 & $\mathrm{X}$ \\
\hline 8 & GH & 66,67 & 66,67 & 56,25 & 189,59 & 63,20 & $\mathrm{X}$ \\
\hline 9 & TA & 83,33 & 75 & 75 & 233,33 & 77,78 & $\sqrt{ }$ \\
\hline 10 & MH & 75 & 83,33 & 81,25 & 239,58 & 79,86 & $\sqrt{ }$ \\
\hline 11 & MA & 91,67 & 83,33 & 87,5 & 262,5 & 87,5 & $\sqrt{ }$ \\
\hline 12 & FM & 83,33 & 83,33 & 87,5 & 254,16 & 84,72 & $\sqrt{ }$ \\
\hline 13 & RA & 75 & 83,33 & 81,25 & 239,58 & 79,86 & $\sqrt{ }$ \\
\hline 14 & $\mathrm{AF}$ & 83,33 & 75 & 75 & 233,33 & 77,78 & $\sqrt{ }$ \\
\hline 15 & FH & 83,33 & 91,67 & 87,5 & 262,50 & 87,50 & $\sqrt{ }$ \\
\hline 16 & HA & 58,33 & 58,33 & 50 & 166,66 & 55,55 & $X$ \\
\hline 17 & $\mathrm{AZ}$ & 83,33 & 83,33 & 87,5 & 254,16 & 84,72 & $\sqrt{ }$ \\
\hline 18 & HJ & 83,33 & 83,33 & 87,5 & 254,16 & 84,72 & $\sqrt{ }$ \\
\hline 19 & WH & 75 & 75 & 75 & 225,00 & 75,00 & $\sqrt{ }$ \\
\hline 20 & AK & 66,67 & 66,67 & 68,75 & 202,09 & 67,36 & $\mathrm{X}$ \\
\hline 21 & HS & 75 & 75 & 87,5 & 237,50 & 79,17 & $\sqrt{ }$ \\
\hline 22 & SR & 83,33 & 66,67 & 68,75 & 218,75 & 72,92 & $\mathrm{X}$ \\
\hline 23 & NP & 75 & 75 & 68,75 & 218,75 & 72,92 & $\mathrm{X}$ \\
\hline 24 & ZW & 83,33 & 75 & 75 & 233,33 & 77,78 & $\sqrt{ }$ \\
\hline 25 & RD & 66,67 & 83,33 & 81,25 & 231,25 & 77,08 & $\sqrt{ }$ \\
\hline 26 & $\mathrm{BF}$ & 75 & 75 & 68,75 & 218,75 & 72,92 & $\mathrm{X}$ \\
\hline 27 & AV & 58,33 & 83,33 & 75 & 216,66 & 72,22 & $\mathrm{X}$ \\
\hline 28 & BY & 75 & 66,67 & 87,5 & 229,17 & 76,39 & $\sqrt{ }$ \\
\hline 29 & SR & 83,33 & 75 & 81,25 & 239,58 & 79,86 & $\sqrt{1}$ \\
\hline 30 & MF & 75 & 83,33 & 75 & 233,33 & 77,78 & $\sqrt{ }$ \\
\hline 31 & NA & 75 & 75 & 75 & 225,00 & 75,00 & $\sqrt{ }$ \\
\hline 32 & SH & 66,67 & 66,67 & 75 & 208,34 & 69,45 & $\mathrm{X}$ \\
\hline 33 & SS & 66,67 & 75 & 68,75 & 210,42 & 70,14 & $\mathrm{X}$ \\
\hline 34 & $\mathrm{HH}$ & 75 & 58,33 & 75 & 208,33 & 69,44 & $X$ \\
\hline 35 & $\mathrm{DZ}$ & 75 & 75 & 81,25 & 231,25 & 77,08 & $\sqrt{ }$ \\
\hline 36 & YY & 83,33 & 75 & 75 & 233,33 & 77,78 & $\sqrt{ }$ \\
\hline \multicolumn{6}{|c|}{ Rata-Rata } & 75,77 & \\
\hline
\end{tabular}

\section{Keterangan:}

$\checkmark$ : siswa yang bersangkutan dinyatakan telah mencapai ketuntasan dari rata-tata total keseluruhan penilaian menulis karangan deskripsi dengan menggunakan peta konsep

$\mathrm{X}$ : siswa yang bersangkutan dinyatakan belum mencapai ketuntasan dari rata-tata total keseluruhan penilaian menulis karangan deskripsi dengan menggunakan peta konsep 
Salah satu contoh peta konsep yang dibuat siswa

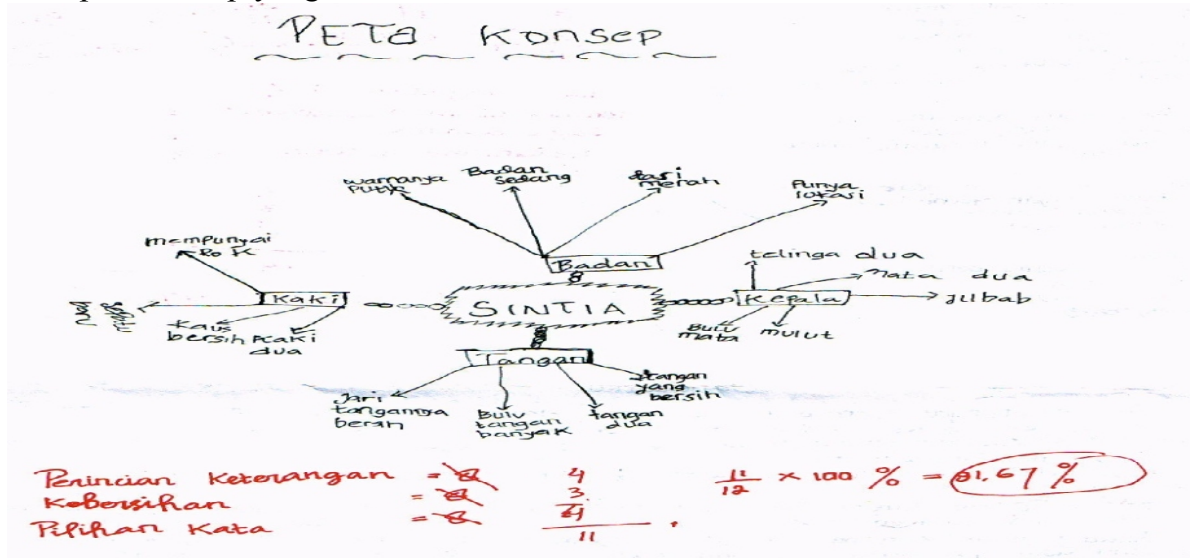

\section{Refleksi}

Hasil kolaborasi menunjukkan bahwa pelaksanaan proses pembelajaran menulis karangan deskripsi dengan menggunakan peta konsep sudah terlaksana sesuai dengan langkah-langkah yang tercantum dalam RPP. Berdasarkan refleksi/diskusi yang dilakukan dengan ketiga observer (kepala sekolah, guru kelas dan teman sejawat) didapatkan kesimpulan bahwa pelaksanaan siklus I ini belum berhasil, sebab persentase ketuntasan yang didapatkan dari total keseluruhan belum mencapai $80 \%$. Setelah didiskusikan tentang hambatan yang menyebabkan belum berhasilnya siklus I ini peneliti dan observer memprediksi kegagalan ini karena alokasi waktu yang sempit. Dimana pada siklus I ini untuk tahap prapenulisan alokasi waktunya sudah cocok satu kali pertemuan ( 2 x 30 menit). Namun untuk tahap penulisan dan pascapenulisan alokasi waktu terlalu sempit. Sehingga siswa menjadi tergesa-gesa dalam merevisi, mengedit dan menyalin karangan yang sudah diperbaiki. Selain itu pada siklus I ini pelaksanaan tahap penulisan terpisah dengan tahap prapenulisan, sehingga diwaktu membahasakan objek yang akan dideskripsikan siswa tidak berhadapan langsung lagi dengan objeknya.

Berdasarkan refleksi yang dilakukan, maka pada siklus berikutnya alokasi waktu pelaksanaan pembelajaran dijadikan 5 × 35 menit. Alokasi waktu ini diperuntukkan untuk prapenulisan dan penulisan $3 \times$ 35 menit, untuk pasca penulisan (perevisian dan pengeditan, dan menyalin kembali karangan, dan publikasi) 2 x 35 menit. Dengan menambah alokasi waktu ini diharapkan pelaksanaan pembelajaran menulis karangan deskripsi dengan menggunakan peta konsep dapat dilakukan dengan baik, sehingga siswa mengalami peningkatan kemampuan menulis karangan deskripsi.

\section{Siklus II}

Siklus II dilakukan pada hari Selasa, tanggal 21 Mei 2013. Sama halnya dengan siklus I, siklus II ini juga terdiri dari perencanaan, pelaksanaan, pengamatan, dan refleksi tindakan. Berikut uraian tahap perencanaan, pelaksanaan, pengamatan, dan refleksi tindakan. Pada siklus II di lakukan perbaikan terhadap alokasi waktu. Alokasi waktu menjadi lebih panjang yaitu 5 x 35 menit yang terdiri dari prapenulisan dan penulisan 3 × 35 menit, untuk pasca penulisan (perevisian dan pengeditan, dan menyalin kembali karangan, dan publikasi) $2 \times 35$ menit.

\section{Perencanaan}

Sama halnya dengan siklus I, pada siklus II tahap perencanaan juga dilakukan pemilihan standar kompetensi dan kompetensi dasar serta indikator yang sama dengan perencanaan siklus I. Begitu juga halnya dengan materi pokok pada perencanaan siklus II memiliki materi pokok yang sama dengan siklus I yaitu tentang pengertian dan langkah-langkah menulis karangan deskripsi dengan menggunakan peta konsep, dimana di dalamnya juga terdapat langkah-langkah membuat peta konsep dari benda yang akan dideskripsikan. 


\section{Pelaksanaan Tindakan}

Sesuai dengan perencanaan, pelaksanaan pembelajaran menulis karangan deskripsi dengan menggunakan peta konsep terbagi menjadi tiga tahap yaitu tahap prapenulisan, penulisan, dan pascapenulisan. Pelaksanaan siklus II ini dilaksanakan sebanyak dua kali pertemuan. Pertemuan pertama dilaksanakan pada hari Selasa tanggal 21 Mei 2013 yaitu dari pukul 13.30 sampai pukul 15.00. Kemudian pertemuan kedua dilanjutkan lagi pada hari Kamis tanggal 23 Mei 2013 dari pukul 13.30 sampai pukul 15.00 .

Pada pelaksanaan siklus II ini tidak semua siswa membawa mainan/benda yang mereka sukai. Peneliti pun menempelkan gambar ayam di papan tulis dan meminta siswa untuk mengamatinya, untuk tahap pendeskripsian guru meminta siswa melihat bunga yang ada di atas meja. Setelah siswa semuanya masuk, baru dilakukan pelaksanaan pembelajaran menulis karangan deskripsi dengan menggunakan peta konsep. Semua kegiatan pembelajaran sama dengan siklus I.

\section{Pengamatan}

Pengamatan siklus II dilakukan observer, yaitu kepala sekolah. Berdasarkan lembar pencatatan dapat diketahui rekapitulasi nilai siswa menulis karangan menggunakan peta konsep.

Tabel 2.

Rekapitulasi Nilai Siswa Dalam Menulis Karangan Deskripsi Menggunakan Peta Konsep pada Siklus II

\begin{tabular}{|c|c|c|c|c|c|c|c|}
\hline \multirow{3}{*}{ No } & \multirow[b]{3}{*}{ Nama Siswa } & \multirow{2}{*}{\multicolumn{3}{|c|}{ POIN PENILAIAN (\%) }} & \multirow[b]{3}{*}{ Jumlah } & \multirow{3}{*}{$\begin{array}{l}\text { Nilai } \\
\text { Akhir } \\
(\%)\end{array}$} & \multirow[b]{3}{*}{ 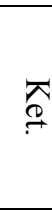 } \\
\hline & & & & & & & \\
\hline & & $\begin{array}{c}\text { Peta } \\
\text { Konsep }\end{array}$ & $\begin{array}{c}\text { Kerangk } \\
\text { a } \\
\text { Karanga } \\
n\end{array}$ & $\begin{array}{c}\text { Hasil } \\
\text { Karang } \\
\text { an }\end{array}$ & & & \\
\hline 1 & WA & 66,67 & 66,67 & 68,75 & 202,09 & 67,36 & $\mathrm{X}$ \\
\hline 2 & $\mathrm{RD}$ & 75 & 75 & 81,25 & 231,25 & 77,08 & $\sqrt{ }$ \\
\hline 3 & MR & 75 & 91,67 & 81,25 & 247,92 & 82,64 & $\sqrt{ }$ \\
\hline 4 & HR & 83,33 & 75 & 81,25 & 239,58 & 79,86 & $\sqrt{ }$ \\
\hline 5 & AJ & 83,33 & 75 & 81,25 & 239,58 & 79,86 & $\sqrt{ }$ \\
\hline 6 & IY & 83,33 & 91,67 & 81,25 & 256,25 & 85,42 & $\sqrt{ }$ \\
\hline 7 & $\mathrm{LS}$ & 75 & 66,67 & 75 & 216,67 & 72,22 & $\mathrm{X}$ \\
\hline 8 & $\mathrm{GH}$ & 75 & 75 & 75 & 225,00 & 75,00 & $\sqrt{ }$ \\
\hline 9 & TA & 83,33 & 83,33 & 75 & 241,66 & 80,55 & $\sqrt{ }$ \\
\hline 10 & $\mathrm{MH}$ & 75 & 83,33 & 81,25 & 239,58 & 79,86 & $\sqrt{ }$ \\
\hline 11 & MA & 91,67 & 83,33 & 87,5 & 262,50 & 87,50 & $\sqrt{ }$ \\
\hline 12 & FM & 83,33 & 91,67 & 81,25 & 256,25 & 85,41 & $\sqrt{ }$ \\
\hline 13 & RA & 75 & 75 & 81,25 & 231,25 & 77,08 & $\sqrt{ }$ \\
\hline 14 & $\mathrm{AF}$ & 83,33 & 91,67 & 75 & 250,00 & 83,33 & $\sqrt{ }$ \\
\hline 15 & FH & 91,67 & 91,67 & 87,5 & 270,84 & 90,28 & $\sqrt{ }$ \\
\hline 16 & HA & 66,67 & 66,67 & 68,75 & 202,09 & 67,36 & $\mathrm{X}$ \\
\hline 17 & $\mathrm{AZ}$ & 83,33 & 75 & 87,5 & 245,83 & 81,94 & $\sqrt{ }$ \\
\hline 18 & HJ & 83,33 & 83,33 & 87,5 & 254,16 & 84,72 & $\sqrt{ }$ \\
\hline 19 & WH & 75 & 75 & 75 & 225,00 & 75,00 & $\sqrt{ }$ \\
\hline 20 & $\mathrm{AK}$ & 66,67 & 83,33 & 68,75 & 218,75 & 72,92 & $X$ \\
\hline 21 & $\mathrm{HS}$ & 75 & 83,33 & 87,5 & 245,83 & 81,94 & $\sqrt{ }$ \\
\hline 22 & SR & 83,33 & 75 & 75 & 233,33 & 77,78 & $\sqrt{ }$ \\
\hline 23 & $\mathrm{NP}$ & 75 & 75 & 75 & 225,00 & 75,00 & $\sqrt{ }$ \\
\hline 24 & ZW & 83,33 & 83,33 & 87,5 & 254,16 & 84,72 & $\sqrt{ }$ \\
\hline 25 & $\mathrm{RD}$ & 75 & 83,33 & 81,25 & 239,58 & 79,86 & $\sqrt{ }$ \\
\hline 26 & $\mathrm{BF}$ & 83,33 & 75 & 75 & 233,33 & 77,78 & $\sqrt{ }$ \\
\hline 27 & $\mathrm{AV}$ & 75 & 75 & 75 & 225,00 & 75,00 & $\sqrt{ }$ \\
\hline 28 & BY & 75 & 75 & 81,25 & 231,25 & 77,08 & $\sqrt{ }$ \\
\hline 29 & SR & 83,33 & 83,33 & 81,25 & 247,91 & 82,64 & $\sqrt{ }$ \\
\hline 30 & $\mathrm{MF}$ & 75 & 75 & 81,25 & 231,25 & 77,08 & $\sqrt{ }$ \\
\hline 31 & NA & 75 & 83,33 & 81,25 & 239,58 & 79,86 & $\sqrt{ }$ \\
\hline
\end{tabular}




\begin{tabular}{|l|l|l|l|l|r|r|l|}
\hline 32 & SH & 58,33 & 75 & 75 & 208,33 & 69,44 & X \\
\hline 33 & SS & 58,33 & 75 & 75 & 208,33 & 69,44 & X \\
\hline 34 & HH & 75 & 75 & 75 & 225,00 & 75,00 & $\sqrt{ }$ \\
\hline 35 & DZ & 75 & 75 & 81,25 & 231,25 & 77,08 & $\sqrt{ }$ \\
\hline 36 & YY & 83,33 & 75 & 87,5 & 245,83 & 81,94 & $\sqrt{ }$ \\
\hline & Rata-Rata & & & & & 78,53 & \\
\hline
\end{tabular}

Keterangan:

$\checkmark$ : siswa yang bersangkutan dinyatakan telah mencapai ketuntasan dari rata-tata total keseluruhan penilaian menulis karangan deskripsi dengan menggunakan peta konsep

$\mathrm{X}$ : siswa yang bersangkutan dinyatakan belum mencapai ketuntasan dari rata-tata total keseluruhan penilaian menulis karangan deskripsi dengan menggunakan peta konsep

Contoh peta konsep karya siswa pada siklus II ini:

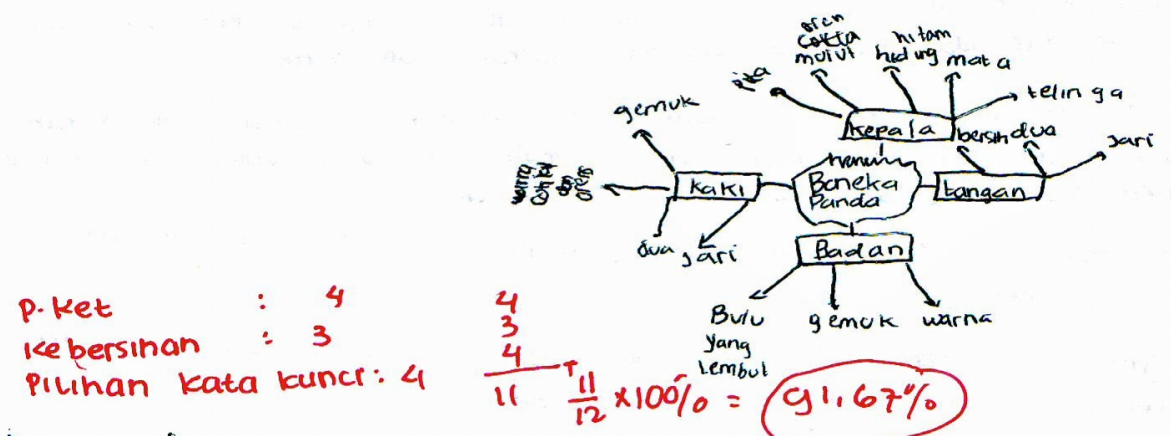

\section{Refleksi}

Nilai menulis deskripsi secara keseluruhan mendapat rata-rata 63,88\% dan persentase ketuntasannya adalah $83,33 \%$. Hal tersebut diperoleh dari jumlah siswa yang tuntas mengikuti tes menulis deskripsi adalah sebanyak 30 orang dan yang belum tuntas 6 orang dari total keseluruhan siswa yang mengikuti UH adalah 36 orang. Dari hasil tes ini dapat dilihat semua indikator keberhasilan pada siklus II berhasil.

\section{PEMBAHASAN}

Pembahasan penelitian ini akan menjawab semua rumusan masalah yang telah dikemukakan. Berikut pembahasan peningkatan kemampuan menulis karangan deskripsi dengan menggunakan peta kosep bagi siswa SD $09 \mathrm{~V}$ Koto Kampung Dalam pada tahap prapenulisan, saat penulisan dan pascapenulisan. Pembahasan didasarkan pada teori-teori yang berkaitan dengan peningkatan kemampuan menulis karangan deskripsi dengan menggunakan peta konsep.

\section{a. Peningkatan kemampuan menulis karangan deskripsi dengan menggunakan peta konsep pada tahap prapenulisan}

Peningkatan kemampuan menulis karangan deskripsi dengan menggunakan peta konsep pada tahap prapenulisan dilakukan dengan memfokuskan kegiatan pembelajaran pada pembuatan peta konsep dari objek yang akan dideskripsikan, kemudian baru membuat kerangka karangan berdasarkan perincian dari objek yang akan dideskripsikan terkumpul dalam bentuk peta konsep.

Tahap prapenulisan pada siklus I sebagian besar sudah berjalan dengan baik. Ini dapat dilihat dari kehangatan dan antusias siswa dalam mengikuti proses pembelajaran menulis tahap prapulisan yang tinggi. Namun belum bisa dikatakan sempurna sebab dalam menentukan benda/objek yang akan dideskripsikan masih dipegang oleh peneliti. Selain itu peneliti juga sudah mampu mengendalikan emosi kelas agar tetap segar dan menyenangkan melalui diadakannya aktifitas bernyanyi yang mengandung lawakan. 
Kegiatan prapenulisan ini pada awalnya difokuskan pada pembuatan peta konsep dan mencatat keterangan dari objek dengan menggunakan peta konsep. Di sini juga telah tampak keberhasilan pelaksanaannya. Peneliti telah membimbing siswa dalam membuat peta konsep dari objek yang akan dideskripsikan.

Pada siklus II kembali dilaksanakan tahap prapenulisan. Mulai dari menentukan objek yang akan dideskripsikan, membuat peta konsep dari objek, membuat perincian dari objek berdasarkan peta konsep, sampai pada membuat kerangka karangan. Namun yang menjadi kekurangan pada saat prapenulisan adalah siswa kurang memahami cara membuat kerangka karangan dengan menggunakan peta konsep. Sehingga pada siklus II ini guru kembali menjelaskan kepada siswa tentang membuat kerangka karangan dengan menggunakan peta konsep.

\section{b. Peningkatan kemampuan menulis karangan deskripsi dengan menggunakan peta konsep pada tahap penulisan}

Pada tahap penulisan dilakukan bimbingan kepada siswa dalam mengembangkan kerangka karangan menjadi karangan deskripsi. Dalam hal ini dapat dilakukan dengan jalan memberikan contoh sebuah paragraf yang berasal dari pengembangan kerangka karangan. Peningkatan kemampuan menulis karangan deskripsi dengan menggunakan peta konsep pada tahap penulisan juga dilakukan dengan mengingatkan siswa dalam menggunakan huruf kapital, tanda baca serta pemilihan kalimat serta penulisan pemenggalan kata dan penggunaan tanda hubung/kata sambung.

Pada siklus I kegiatan tahap penulisan kurang terlaksana dengan optimal. Hal ini disebabkan karena kurangnya bimbingan dan arahan dari guru saat menulis karangan. Sehingga karangan yang dihasilkan siswa belum sempurna, misalnya dalam pengembangan karangan dalam satu paragraf hanya terdiri dari satu/dua kalimat saja dan itupun belum sempurna, begitu pun dalam penggunaan ejaan, huruf kapital, tanda titik dan tanda koma.

Selain itu ketidakberhasilan siklus I disebabkan oleh terpisahnya tahap prapenulisan dengan pascapenulisan. Sehingga siswa kesulitan dalam menggambarkan temannya, sebab pelaksanaan tahap prapenulisan dilakukan pada hari Selasa tanggal 14 Mei 2013, sedangkan tahap penulisan dilaksanakan pada hari Kamis tanggal 16 Mei 2013. Hal ini mengakibatkan siswa kesulitan dalam mengembangkan kerangka karangan untuk menceritakan keadaan teman yang sudah tercover dalam peta konsep.

Pada siklus II kegiatan penulisan sudah terlaksana secara baik. Segala kekurangan pada siklus I sudah diatasi pada siklus II. Peneliti telah memberikan bimbingan dan arahan pada siswa saat menulis karangan deskripsi. Karangan yang dihasilkan siswa sudah baik, sebab siswa sudah mulai mampu menge mbangkan kerangka karangan menjadi karangan deskripsi. Demikian juga dalam pemakaian huruf kapital, tanda titik dan tanda koma sebagian besar sudah digunakan. Disamping itu dalam penulisan paragraf siswa sudah cukup memahami. Secara totalitas pada tahap penulisan siklus II siswa telah mengalami peningkatan dan mencapai indikator keberhasilan yang telah peneliti tetapkan secara keseluruhan.

\section{c. Peningkatan kemampuan menulis karangan deskripsi dengan menggunakan peta konsep pada tahap pascapenulisan.}

Pada saat pascapenulisan dilakukan kegiatan merevisi, mengedit, menyalin kembali, dan membacakan karangan terbaik di depan kelas. Namun tahap pascapenulisan pada siklus I kurang terlaksana dengan baik, sebab alokasi yang terlalu singkat. Sehingga peneliti tergesa-gesa dalam memberikan arahan dan bimbingan kepada siswa sewaktu melakukan perevisian dan pengeditan serta menyalin kembali karangan yang telah direvisi dan diedit tersebut.

Berdasarkan refleksi dan diskusi yang peneliti lakukan dengan observer untuk siklus II alokasi waktu diperpanjang menjadi 5 × 35 menit. Alokasi waktu ini digunakan untuk tahap prapenulisan, penulisan sebanyak 3 x 35 menit dan untuk tahap pascapenulisan (mengedit, merevisi, menyalin kembali dan publikasi) sebanyak 2 × 35 menit. Dari keseluruhan pelaksanaan siklus I dilakukan penilaian proses, penilaian peta konsep, penilaian kerangka karangan, dan nilai karangan deskripsi yang dihasilkan rata-rata. Untuk mencari nilai akhir menulis karangan deskripsi dilakukan dengan menjumlahkan semua penilaian (peta konsep + kerangka karangan + nilai hasil karangan) kemudian hasilnya dibagi empat. Pada siklus I dari 36 orang siswa yang mengikuti ulangan harian atau tes belajar, hanya 23 orang siswa yang mencapai indikator keberhasilan atau KKM yang ditetapkan oleh peneliti (>75\%) sedangkan 13 orang lagi belum mencapai ketuntasan $(<75 \%)$. 
Kegiatan pascapenulisan siklus II sudah berjalan sesuai dengan RPP yang dirancang. Siswa telah melakukan perevisian dan pengeditan dengan teman sebangkunya dibawah arahan dan pengawasan peneliti. Kegiatan menyalin kembali karangan yang telah direvisi dan diedit juga telah terlaksana dengan baik. Kegiatan ini dapat terlaksana karena waktu yang cukup untuk melakukan tahap perevisian, pengeditan dan publikasi. Jika dilihat dari totalitas penskoran nilai baik itu proses, peta konsep, kerangka karangan, dan nilai hasil karangan, siklus II sudah mencapai indikator keberhasilan dengan skor ketuntasan pembelajaran sudah mencapai $80 \%$. Sebab dari 36 orang siswa yang mengikuti tes hasil belajar, siswa yang tuntas 30 orang dan yang belum tuntas 6 orang.

Dari hasil penilaian proses, penilaian peta konsep, penilaian kerangka karangan, dan penilaian hasil karangan deskripsi, dengan diperolehnya ketuntasan belajar sebesar 83,33\%, peneliti dan observer beserta teman sejawat menyepakati bahwa penelitian tentang peningkatan keterampilan menulis karangan deskripsi dengan menggunakan peta konsep bagi siswa kelas IV SD 09 V Koto Kampung Dalam telah berhasil. Hal tersebut sesuai dengan perbandingan nilai karangan deskripsi melalui penggunaan peta konsep pada siswa kelas IV SD 09 V Koto Kampung Dalam.

Tabel 3

Perbandingan Nilai Kemampuan Menulis Karangan Deskripsi Siswa Melalui Penggunaan Peta Konsep Siswa Kelas IV 09 V Koto Kampung Dalam

\begin{tabular}{|c|c|c|c|}
\hline \multirow{2}{*}{ No } & \multirow{2}{*}{ Nama Siswa } & \multicolumn{2}{|c|}{ Perbandingan Skor Siswa } \\
\cline { 3 - 4 } & & Skor Siswa Siklus I & Skor Siswa Siklus II \\
\hline 1 & WA & 56,94 & 67,36 \\
\hline 3 & RD & 75,00 & 77,08 \\
\hline 4 & MR & 77,08 & 82,64 \\
\hline 5 & HR & 74,31 & 79,86 \\
\hline 6 & AJ & 79,86 & 79,86 \\
\hline 7 & IY & 82,64 & 85,42 \\
\hline 8 & GH & 70,14 & 72,22 \\
\hline 9 & TA & 63,20 & 75,00 \\
\hline 10 & MH & 77,78 & 80,55 \\
\hline 11 & MA & 79,86 & 79,86 \\
\hline 12 & FM & 87,50 & 87,50 \\
\hline 13 & RA & 84,72 & 87,50 \\
\hline 14 & AF & 79,86 & 77,08 \\
\hline 15 & FH & 77,78 & 83,33 \\
\hline 16 & HA & 87,50 & 90,28 \\
\hline 17 & AZ & 55,55 & 61,80 \\
\hline 18 & HJ & 84,72 & 81,94 \\
\hline 19 & WH & 84,72 & 84,72 \\
\hline 20 & AK & 75,00 & 75,00 \\
\hline 21 & HS & 67,36 & 72,92 \\
\hline 22 & SR & 79,17 & 77,78 \\
\hline
\end{tabular}




\begin{tabular}{|c|c|c|c|}
\hline 23 & NP & 72,92 & 75,00 \\
\hline 24 & ZW & 77,78 & 84,72 \\
\hline 25 & RD & 77,08 & 79,86 \\
\hline 26 & BF & 72,92 & 77,78 \\
\hline 27 & AV & 72,22 & 75,00 \\
\hline 28 & BY & 76,39 & 77,08 \\
\hline 29 & SR & 79,86 & 82,64 \\
\hline 30 & MF & 77,78 & 77,08 \\
\hline 31 & NA & 75,00 & 79,86 \\
\hline 32 & SH & 69,45 & 69,44 \\
\hline 33 & SS & 70,14 & 69,44 \\
\hline 34 & HH & 69,44 & 75,00 \\
\hline 35 & DZ & 77,08 & 77,08 \\
\hline 36 & YY & 77,78 & 81,94 \\
\hline & Rat-Rata & 75,54 & 78,53 \\
\hline
\end{tabular}

Berdasarkan tabel di atas, dapat dilihat bahwa siswa yang mencapai KKM pada siklus I adalah 23 dari jumlah siswa yang mengikuti UH 36 dengan persentase 63,88\%. Sedangkan pada siklus II jumlah siswa yang tuntas 30 orang dari 36 orang siswa yang mengikuti UH dengan persentase ketuntasan $83,33 \%$.

\section{KESIMPULAN DAN SARAN \\ KESIMPULAN}

Dari pelaksanaan penelitian tentang peningkatan kemampuan siswa dalam menulis karangan deskripsi dapat disimpulkan bahwa pembelajaran menulis karangan deskripsi dengan menggunakan peta konsep dapat meningkatkan aktivitas dan hasil belajar siswa. Hal ini dapat dilihat pada siklus I tahap prapenulisan, penulisan, dan pascapenulisan dengan rata-rata persentase 63,88\%. Sedangkan pada siklus II tahap prapenulisan, penulisan, dan pascapenulisan dengan rata-rata persentase $83,33 \%$ dengan peningkatan sebesar $19,95 \%$.

\section{SARAN}

Berdasarkan hasil analisis data dapat disarankan kepada:

1. Untuk siswa agar dapat menggunakan kemampuan menulis karangan deskripsi menggunakan peta konsep sehingga meningkatkan aktivitas dan hasil belajar siswa.

2. Untuk guru SD pada umumnya peneliti menyarankan untuk menggunakan peta konsep dalam melaksanakan pembelajaran menulis.

3. Untuk sekolah supaya mengadakan sarana dan prasarana yang memadai untuk meningkatkan kemampuan menulis karangan siswa SD.

\section{DAFTAR PUSTAKA}

Hamalik, Oemar. 2011. Proses Belajar Mengajar. Cetakan ke-12. Jakarta: Bumi Aksara

Lutfri, M.S. 2007. Strategi Pembelajaran Biologi.UNP Press

Resmini, Novi dan Juanda Dadan. 2007. Pendidikan Bahasa dan Sastra Indonesia Di Kelas Tinggi. UPI Pres

Sudjana, Nana. 2005. Dasar-Dasar Proses Belajar Mengajar. Bandung: Sinar Baru Algasindo.

Syafi’'i, Imam. 1990. Bahasa Indonesia Profesi. IKIP Malang. 
Syamra, Yesi. 2009. "Peningkatan Kemampuan Menulis Karangan Deskripsi Dengan Menggunakan Peta Konsep Bagi Siswa Kelas IV SD Negeri 36 Cengkeh Kecamatan Lubuk Begalung Padang”. Universitas Negeri Padang

Tarigan, Hendry Guntur. Menulis Sebagai Suatu Keterampilan Berbahasa. Bandung: Angkasa

Trianto, M.P.d. 2009. Mendesain Model Pembelajaran Inovatif-Progresif. Jakarta: Media Group.

Wardani, dkk. 2003. Penelitian Tindakan Kelas. Jakarta: Pusat Penerbitan Universitas Terbuka. 